\title{
QUALITY CONTROL PROCESS OF MANUFACTURED COMPOSITE STRUCTURES
}

\author{
RAFAŁ SZYMAŃSKI \\ Center for Composite Technologies, Institute of Aviation, Al. Krakowska 110/114, 02-256 Warsaw \\ rafal.szymanski@ilot.edu.pl
}

\begin{abstract}
The paper includes a description of the composite material used in the aviation industry. It presents the technological development of composites in terms of their use in the most important elements of the aircraft structures, such as a spar and aircraft wing sheathing, which are subjected to high loads during operation. The type of the material implemented for production was listed and the most commonly occurred incompatibilities during the carbon pre-impregnate manufacture and transport were described.

The manufacture diagram of composite elements with a polymer matrix was presented and the quality control system carried out at each mentioned stage (material storage, defrosting, cutting of dies, structure forming, polymerisation) was discussed.

The methods of non-destructive tests of carbon laminates in a polymer matrix were also listed, describing the most effective of them, i.e. a method of ultrasonic tests.

The conclusions were drawn and the development possibilities of ultrasonic tests both in terms of quality improvement and reduction of time for detecting incompatibilities in composite structures were described.
\end{abstract}

Keywords: pre-impregnate, composite technology, non-destructive tests with the use of an ultrasonic method.

\section{INTRODUCTION}

Composite materials gradually replace other, traditional materials used in reliable structural components of the aircraft. Materials with a polymer matrix reinforced with fibres have high strength parameters and low density compared to the aluminium alloys. It means that it is possible to manufacture an equally good element with a much smaller empty weight. In aviation, it contributes to the transport possibility of a larger quantity of goods, taking a larger number of passengers on board or overcoming a longer distance with the same amount of fuel. In addition, the composite is resistant to corrosion and shows fatigue properties that are comparable with other materials used in aviation. Therefore, a great interest in these materials in aviation, automotive, sport and even in medicine is observed. The development and implementation for manufacture of modern thermosetting polymer plastics allowed to replace traditional aluminium alloy materials with the composite materials.

Following the increasing requirements of the global aviation industry, a programme for construction and testing of composite I-23 Manager aircraft and ILX-27 helicopter was created in 
Institute of Aviation. In these designs, inter alia, the high strength spars of carbon fibre made of pre-impregnates [1] were developed.

The constant progress of composite materials forces the development of new manufacturing technologies of structures, and thorough quality control at every stage of the manufacturing process. No derogation from the procedures during the manufacture of composite structures is permitted. The negligence at any stage of the process can result in the aircraft crash and death of many passengers.

The most commonly used technology of the construction of composite elements is the so-called pre-impregnated method. The advantages of manufacturing composites in this technology, from the perspective of their use in the aviation structures, include: minimum quantity of porosity $(<1 \%)$, high mechanical properties, high quality of the surface of composite elements, repeatability, full control of the curing process (temperature, pressure).

\section{QUALITY CONTROL AT THE PRE-IMPREGNATE MANUFACTURE AND TRANSPORT STAGE}

\subsection{Quality control at the pre-impregnate manufacture stage}

The material created of at least two components with different physical and chemical properties is called a composite. The composite created in this manner includes better or other properties in relation to the applied components. The composite elements may be in the form of laminates, sandwich structures with homogeneous (foam) and cellular (honeycomb type structure) fillers or hybrid structures. The polymer composite consists of resin (epoxy, polyester or phenolic) constituting a matrix, and reinforcement fibres (glass, carbon or aramid) which give stiffness and strength to the composite.

Despite the existence of many composite technologies (manual "wet" lamination, infusion, RTM - release to manufacturing), the pre-impregnate technology is used in aviation. The pre-impregnate means the reinforcement impregnated with a specific quantity of resin of an incomplete cycle of polymerisation and protected on one or two sides with a protection film. Pre-impregnates occur in the form of unidirectional continuous fibres called a tape or rowing and bi-directional woven fibres called fabrics. There are fabrics in the following weaves: PLAIN, TWILL, SATIN or in the form of multiaxial sewn fabrics. The manufacture diagram of pre-impregnates was shown in Figure 1 [2].
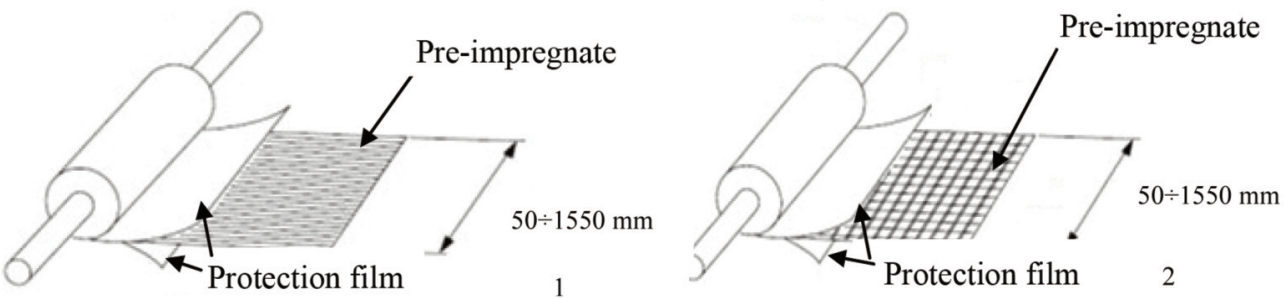

Fig. 1. Diagram of produced pre-impregnates: 1 - tape, 2 - fabrics [2]

The matrix evenly spreads resin, which binds the fibres on the reinforcement surface and maintains them in the chosen orientation.

The composite material quality control has its beginning at the manufacture stage of the material itself. During the pre-impregnate manufacture, the uneven distribution or direction of arranging the reinforcement fibres, improper participation of reinforcement fibres in the pre-impregnate volume, uneven distribution of resin on the entire material surface, the improper degree of curing the base resin may occur. 
Irregularities during the manufacture of pre-impregnated fabrics and tapes directly contribute to the final product. Due to this fact, it is very important to diagnose and remove these irregularities by the manufacturer supplying the material. The recipient has few opportunities to detect manufacturing defects at the commissioning stage, therefore, it must solely rely on the quality certificates of the delivered products.

As a rule, the area on the pre-impregnate roller, which does not meet the quality standards, is marked with warning stickers by the manufacturer. [3].

\subsection{Quality control during the pre-impregnate transport}

The produced material is hermetically packed in a plastic bag and in a carton with a full description of the product, which includes: material name and type, material quantity in linear metres, expiration date. The product label is shown in Figure 2.

Until the time of transport, in order to minimise the spontaneous polymerisation, the pre-impregnate is stored in the freezer at $-18^{\circ} \mathrm{C}$.

During transport, the material must be also stored at the negative temperature. It is important because the pre-impregnate has a short expiration date. Normally, for the material stored at $0^{\circ} \mathrm{C}$, the expiration date is 3 months, and for the temperature of $-18^{\circ} \mathrm{C}$, it is $12 \div 18$ months.

The quality control at this stage involves placing temperature sensors in the material storage places, systematic checking and

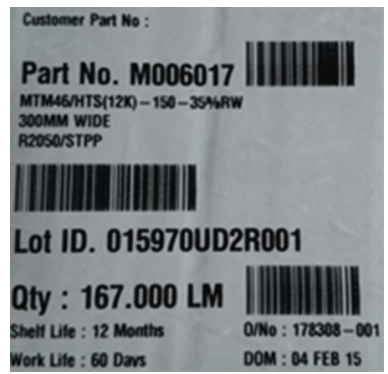

Fig. 2. Carbon pre-impregnate label [Szymański, 2016] automation of the temperature control.

\section{QUALITY CONTROL DURING MANUFACTURE OF COMPOSITE STRUCTURES}

During the manufacture process of composite structures of the pre-impregnate, it is very crucial to provide thorough quality control and to conduct it at every stage [7]. The pre-impregnate is an expensive material sensitive to external factors, so it must be specially controlled. The general diagram of the manufacture process was presented in Figure 3.

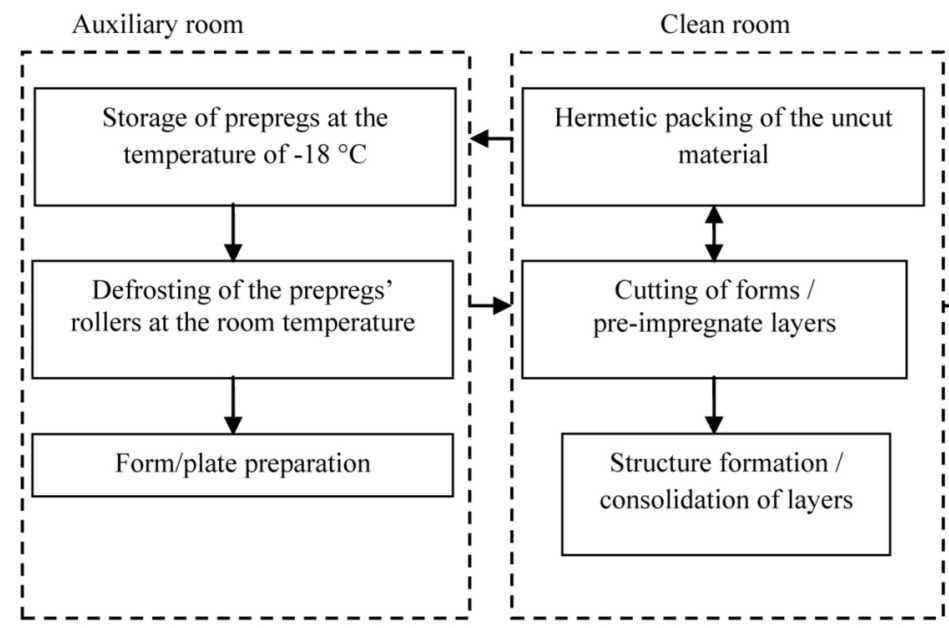

Furnace

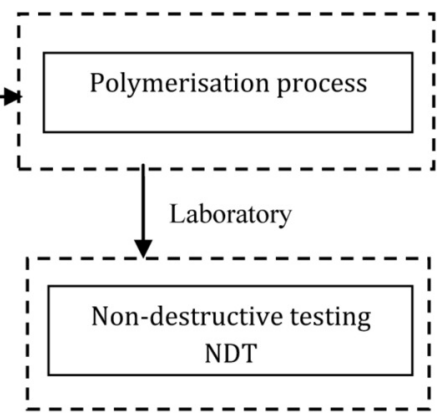

Fig. 3. General diagram of the manufacture process [Szymański, 2016] 


\subsection{Pre-impregnate storage}

The pre-impregnate should be stored in a tightly closed bag in the freezer at $-18^{\circ} \mathrm{C}$. During the storage, it is important to regularly control the temperature and the expiration date. The excessively high temperature or an unduly long period of storing the pre-impregnate may lead to excessive curing of the base resin, and consequently, they may prevent the correct combination of the laminate layers during its final polymerisation. The result of non-compliance with these conditions is the formation of delamination with different sizes and intensity, which are visible during non-destructive testing NDT (Non-Destructive Testing). The method of the material storage control was demonstrated in Figure 4.
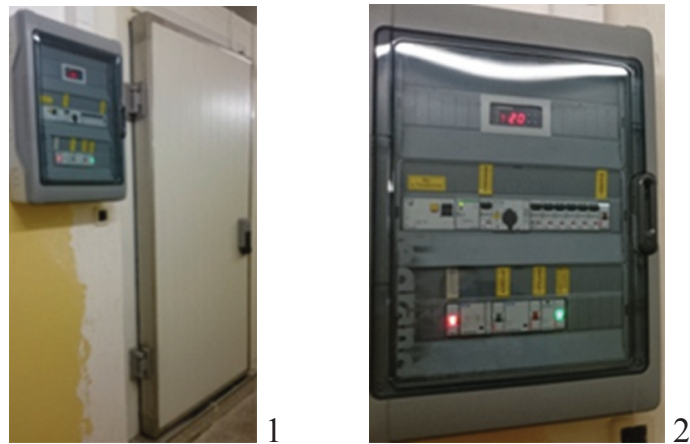

Fig. 4. Pre-impregnate storage

1 - freezer general view,

2 - temperature controller [Szymański, 2016]

\subsection{Defrost of pre-impregnates}

Defrost of pre-impregnates takes place in the support room at the room temperature for the period of $24 \div 48$ hours. At this stage, it is important not to open a hermetically closed plastic bag before reaching the ambient temperature by the material. The pre-impregnate low temperature in combination with higher temperature in the air would result in an undesirable effect of water steam condensation on their surface. The result of the contact of steam, a drop of water with the composite material could result in delamination and failure in curing the resin. At this stage, the quality control involves checking whether the plastic bag was unsealed, and filling in the product card, which includes, inter alia, the date and time of taking the material out of the freezer, and the ambient temperature. The example product card was presented in Figure 5.

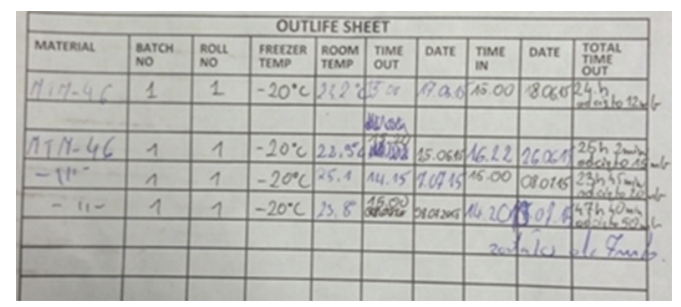

Fig. 5. Product card [Szymański, 2016]

\subsection{Cutting of dies and layers}

In order to implement the composite structure, it is important to cut out the properly dimensioned pre-impregnate layers. Cutting is automatically performed on the plotter in a special, clean room, 
the so-called clean room. The cut out forms can be directly passed to the personnel executing the structure or placed in the refrigerator in the cooler at $-18^{\circ} \mathrm{C}$. In such conditions, the spontaneous polymerisation process of base resin proceeds faster than at $-18^{\circ} \mathrm{C}$, however, the possibility of quick implementation of the forms for manufacture is provided due to shortening of the defrost time [4]. The quality control should make it possible to check if the remaining material was hermetically packed and put back to the freezer. It is also necessary to check if the product card, which should include: quantity of the cut off material, temperature and storage time outside the freezer, was filled in.

\subsection{Structure formation / arrangement of layers}

Before starting the arrangement of the pre-impregnate layers, it is necessary to check if the form, on which the structure will be implemented, was properly prepared. In order to avoid constant sticking of the material, the form should be covered with a separating layer in the form of liquid or PTFE foil, and additionally, the surface should be clean, free from dust, dirt, lint, etc.

The process of arranging the layers should be carried out in the clean room. The employees must be provided with the documentation including specific dimensions and a sequence of successive layers of the pre-impregnate. During the structure formation, the personnel should wear dust free (silicone, nitrile) gloves while working. At this stage, it is easy to let in the impurities or fragments of foreign materials (protection foil, adhesive tapes, ends of the blades), which make the connection of adjacent layers impossible. The example of delamination caused by inclusion of a foreign material was presented in Figure 6 [5].

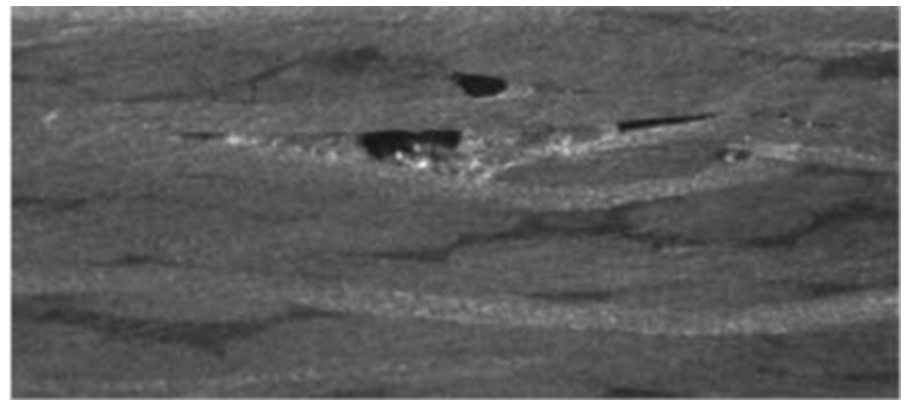

Fig. 6. The carbon laminate cross section with delamination caused by the impurity let in during the arrangement of the pre-impregnate layers [Szymański, 2016]

The arrangement and pressing of layers should be carried out carefully and under self-control. At this stage, it is important to remove air bubbles between the layers, which will be difficult to remove in the further process. The example of voids and porosity of the laminate was demonstrated in Figure 7 [5].

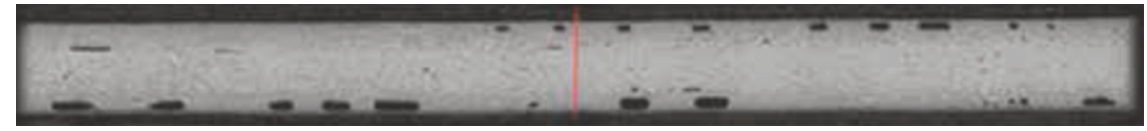

Fig. 7. Tomographic vertical cross-section through the carbon laminate thickness with the defects, such as voids and porosity [Szymański, 2016]

It is necessary to fill in the product card, in which the information compliant with Figure 8 is included. 


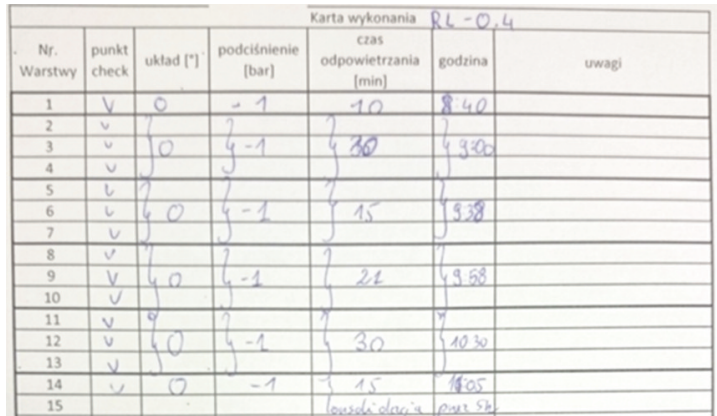

Fig. 8. Consolidation card of the carbon pre-impregnate product [Szymański, 2016]

\subsection{Polymerisation process}

The polymerisation process is the most important stage during the manufacture of composite structures. It is important to hermetically close the element in a vacuum bag. In case of leakage, air will be sucked from the outside and injected to the composite inside, and there will be voids in case of insufficient pressure. The curing process itself must be subjected to the control. This process should be carried out in accordance with the documentation provided by the producer. The course of the temperature and pressure cycle, inconsistent with the specifications, results in the occurrence of porosity in large numbers in the form of concentration of air micro-bubbles. The curing process should be recorded and tested the next day. The example process of curing the pre-impregnate for MTM 46 material was presented in Figure 9.

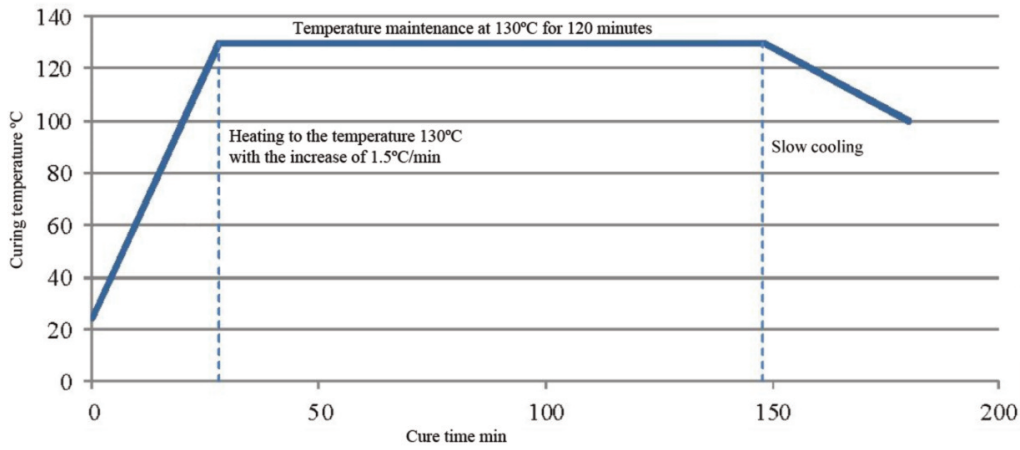

Fig. 9. MTM 46 pre-impregnate curing process [Szymański, 2016]

\subsection{Non-destructive tests}

Non-destructive tests (NDT) - constitute the final stage of the quality control. In these tests, all the defects, which occurred at the previous stages, are detected. The non-destructive testing techniques are used for selecting the material discontinuities and assessing the material properties without causing their performance properties [4]. The defects in the composite include discontinuities, such as bubbles, voids, and cells, as well as unstuck surfaces, delamination or inclusions of foreign materials.

The composite non-destructive tests include the following methods:

- tap test,

- resonant, 
- thermovision,

- interferometric,

- radiographic,

- ultrasonic.

Composite materials may pose a lot of difficulties during the tests. They must be carried out by a qualified employee with a certificate for carrying out the tests. Unlike the isotropic materials such as steel and aluminium alloys, the laminates have different acoustic impedances within the material. The impedance for epoxy resin is $Z_{z}=3.3 \times 10^{6} \mathrm{~kg} / \mathrm{m}^{2} \mathrm{~s}$, and for a carbon fibre, it is $Z_{z}=7.2 \times 10^{6} \mathrm{~kg} / \mathrm{m}^{2} \mathrm{~s}$ (in case of propagation of waves in the transverse direction of fibres). The second limitation is the composite material anisotropy. The strong anisotropy of the carbon laminate in the microscopic scale results from two factors, firstly, from the directed arrangement of reinforcement fibres in individual layers, and secondly, from the fact that the same carbon fibres have different flexural moduli in the longitudinal and transverse direction. Young's modulus of the carbon fibre (graphite) in the longitudinal direction is much higher than in the transverse direction. It is the property results in the situation that anisotropy of carbon laminates is definitely higher than the laminates with a different type of reinforcement fibres (e.g. glass) [4].

Due to the difficulties of detecting defects in the composite materials, the ultrasonic method is mainly used. This method uses the impact of the elastic properties and the material structure homogeneity for the propagation of ultrasonic waves.

The test is carried out with the use of ultrasonic heads generating longitudinal waves (directed at the angle of $0^{\circ}$ in relation to the normal one to the tested material surface) with the frequency of $2 \div 10 \mathrm{MHz}$. Scanning involves moving the ultrasonic head on the entire element surface in accordance with the determined direction. The scanning diagram was shown in Figure 10 [6].
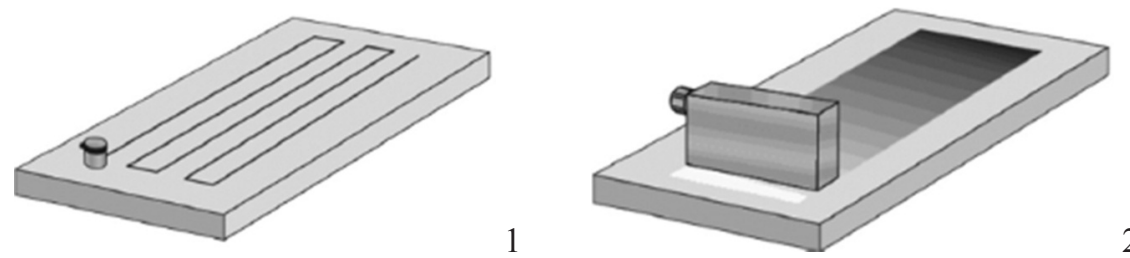

Fig. 10. Flat element scanning with the following technique: 1 - conventional of A-scan type, 2 - linear head of Phased Array type [5]

During the head movement, ultrasonic waves constantly go through the material, and when they encounter the defect, they reflect back and return to the head partially attenuated. The ultrasonic test diagram was shown in Figure 11 [3].
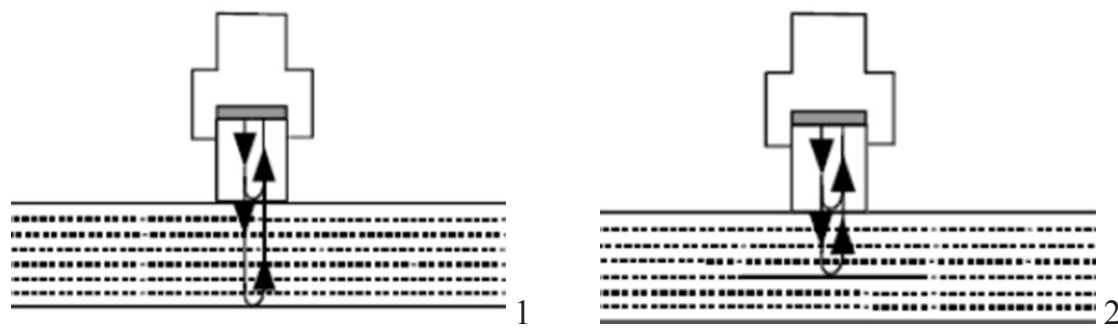

Fig. 11. Principle of testing the composite with the use of A-scan technique: 1 - composite without defects, 2 - composite with a defect [3] 
Currently, professional multiple-transducer heads with the possibility of scanning in several sections (A-scan, B-scan, C-scan) are used in the most modern quality control departments. The display of $A$ type presents the relationship of the ultrasonic signal amplitude in the function of transition time or the distance from the head. The display of $B$ part shows a vertical cross section of the tested material thickness along the head location line. The display of $\mathrm{C}$ type presents the image of the tested element in the top view. Thanks to the display possibilities of A, B and C types, the controller has a transparent image to analyse. Such display was shown in Figure 12 [6].
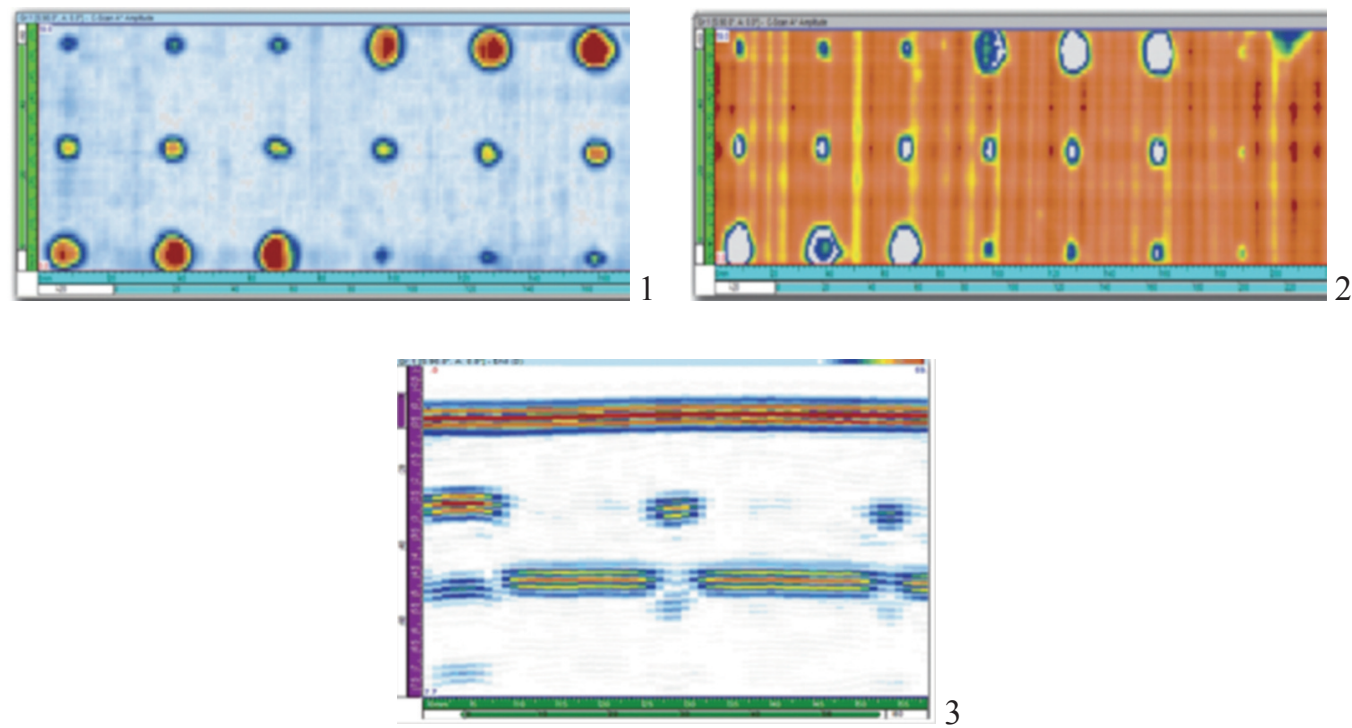

Fig. 12. Display of the following types:

1 - C - amplitude scan of the laminate sample with holes,

$2-\mathrm{C}$ - amplitude scan of the bottom echo of the laminate sample with holes,

3 - B - scan of the cross section containing three discontinuities in the form of holes [6]

\section{CONCLUSIONS}

Not only the errors made during the element production, but also the irregularities occurring during the pre-impregnate manufacture and transport have an impact on the final product quality.

The most common defects during the pre-impregnate manufacture include: uneven distribution or direction of arranging the reinforcement fibres, improper participation of reinforcement fibres in the pre-impregnate volume, uneven distribution of resin on the entire pre-impregnate surface.

The most common causes of irregularities (delamination, stratification, incorrect arrangement of layers, unsealing of a vacuum bag) result from a human factor - it is estimated that this is about $60 \%$.

In order to minimise the errors made during the entire process, it is important to implement detailed and clear procedures of the proper production of composite structures of the pre-impregnate and to extend the quality control.

The most accurate and the most commonly used non-destructive method for testing the composite includes an ultrasonic method, which is applied in testing of more than $80 \%$ of composite elements.

In order to accelerate and improve the quality of non-destructive tests, it is crucial to automate the process of ultrasonic tests and use multi-transducer heads with different position angles in such a manner as to make it possible to scan the entire material volume during one transfer of a set of heads. 


\section{BIBLIOGRAPHY}

[1] Wiśniowski W., 2014, „Specjalizacje Instytutu Lotnictwa - Przegląd i Wnioski” ["Specialisations of Institute of Avition - Review and Results"], Prace Instytutu Lotnictwa [Works of Institute of Avition], 2(235), pp. 7-16.

[2] http://www.kompozyty.milar.pl/strona-prepegs-2-13.

[3] http://www.hexcel.com/resources/datasheets/brochure-data-sheets/preimpregnate_technology.pdf

[4] Mackiewicz S., Góra G., 2005, Ultradźwiękowe badania konstrukcji kompozytowych w przemyśle lotniczym [Ultrasonic tests of composite structures in aviation], „XI Seminarium Nieniszczace Badania Materiatów" ["The 11th Seminar of Material Non-destructive Tests"],

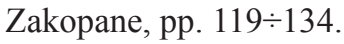

[5] Mackiewicz S. and Katz T., 2013, „Technika Phased Array - cz. I” [”Phased Array Technique - part I'], Materiały Kompozytowe [Composite Materials"], 1/2013, pp. 26-29.

[6] Mackiewicz S. and Katz T., 2013, „Technika Phased Array - cz. II” ['Phased Array Technique - part II"], , Materiały Kompozytowe [Composite Materials"], 1/2013, pp. 34-38.

[7] Surowska B. and Bieniaś J. „Wytwarzanie kompozytów metoda autoklawową i ocena ich jakości" ["Manufacture of composites with a autoclave metod and assessment of their quality"], Lublin University of Technology, Faculty of Mechanical Engineering, pp. 488-500.

\section{PROCES KONTROLI JAKOŚCI WYTWARZANYCH STRUKTUR KOMPOZYTOWYCH}

\section{Streszczenie}

Artykuł zawiera opis materiału kompozytowego stosowanego w przemyśle lotniczym. Przedstawia rozwój technologiczny kompozytów pod kątem ich zastosowania w najważniejszych elementach konstrukcji lotniczych takich jak dźwigar i pokrycie skrzydła samolotu, które poddawane są dużym obciążeniom podczas eksploatacji. Wymieniono rodzaj wdrożonego do produkcji materiału węglowego oraz opisano najczęściej występujące niezgodności podczas produkcji i transportu preimpregnatu węglowego.

Przedstawiono schemat produkcji elementów kompozytowych o osnowie polimerowej oraz omówiono system kontroli jakości przeprowadzany na każdym $\mathrm{z}$ wymienionych etapów (przechowywanie materiału, rozmrażanie, cięcie wykrojników, formowanie struktury, polimeryzacja).

Wymieniono również metody badań nieniszczących laminatów węglowych w osnowie polimerowej, opisując najskuteczniejszą z nich tj. metodę badań ultradźwiękowych.

Wyciągnięto wnioski oraz opisano możliwości rozwoju badań ultradźwiękowych pod kątem zarówno poprawy jakości, jak i zmniejszenia czasu wykrywania niezgodności w strukturach kompozytowych.

Słowa kluczowe: preimpregnat, technologia kompozytowa, badania nieniszczące metodą ultradźwiękową. 